\title{
A MISE-EN-SCÈNE DO "COMER EM ÉVORA": NARRATIVA, VISUALIDADE E STORYTELLING EM TORNO DO CONSUMO ENOGASTRONÓMICO
}

\section{THE MISE-EN-SCÈNE OF “EATING IN ÉVORA”: NARRATIVE, VISUALITY AND STORYTELLING ON FOOD AND WINE CONSUMPTION}

\author{
Rosalina Pisco Costa ${ }^{1}$
}

\begin{abstract}
Resumo: Analisam-se neste texto as estratégias discursivas mobilizadas para a (re)construção social de lugares e identidades tendo em vista os fins da promoção e consumo turístico enogastronómico. Foi elaborada uma análise qualitativa de conteúdo de base indutiva, alinhada com os pressupostos da groundedtheory e inspirada pelos princípios da análise de narrativas visuais e storytelling à obra Comer em Évora: os restaurantes e as suas receitas, do fotógrafo português J. H. Coelho (2014). A ênfase na história, tradição, autenticidade e personalização, seja pela via familiar, seja pela figura do chef e cozinha de autor, são as estratégias discursivas que ora reforçam o estereótipo cultural da tradicional cozinha alentejana; ora afirmam uma cozinha diferente, criativa, inovadora e exótica.
\end{abstract}

Palavras-chave: Consumo; Escrita Enogastronómica; Estudos de Turismo; Métodos Visuais; Turismo Enogastronómico.

\begin{abstract}
This text analyses the discursive strategies used in the social (re)construction of places and identities aiming the promotion and consumption, from a food and wine tourism perspective. Empirically, it draws on a qualitative analysis, carried out from an inductive perspective, in line with the assumptions of grounded-theory and inspired by visual and storytelling narratives over the book "Comer em Évora: the restaurants and its recipes", authored by the Portuguese photographer J. H. Coelho (2014). The emphasis on history, tradition, authenticity and personalization, either by the family life or the figure of the chef and author cuisine, constitute the discursive strategies used to reinforce both the cultural stereotype on the traditional Alentejo cuisine and a different, creative, innovative and exotic cuisine.
\end{abstract}

Keywords: Consumption; Food Writing; Tourism Studies, Visual Methods; Food and Wine Tourism.

\section{Introdução}

A nossa cozinha é, em larga parte, a procura do prazer (Francisco Martins Ramos, Breviário Alentejano, 2006, p. 94).

A afirmação de que a [nossa] cozinha é a busca de prazer é indissociável da constatação de que há uma dimensão não apenas sensorial, também cognitiva, emocional e simbólica associada ao ato de comer. Com base neste pressuposto, a gastronomia pode ser perspetivada como um conjunto de práticas culinárias e, simultaneamente, um campo

\footnotetext{
${ }^{1}$ Doutorada em Ciências Sociais (Sociologia) pelo Instituto de Ciências Sociais da Universidade de Lisboa (ICS-UL, 2011). Professora Auxiliar no Departamento de Sociologia, Escola de Ciências Sociais da Universidade de Évora e Investigadora Integrada no CICS. NOVA. UÉvora - Centro Interdisciplinar de Ciências Sociais, Portugal. E-mail: rosalina@uevora.pt
} 
discursivo que legitima a preparação e o consumo de alimentos. A gastronomia afirmase, portanto, como textualmente construída (FERGUSON, 1998; FERGUSON; ZUKIN, 1995). É com este enquadramento em pano de fundo que se interrogam neste texto os modos através dos quais a literatura enogastronómica contribui para a (re)construção social de um determinado lugar como destino turístico. Empiricamente, analisa-se a obra Comer em Évora: os restaurantes e as suas receitas ${ }^{2}$, livro editado em 2014, que agrega fotografias e textos em torno de um conjunto de restaurantes da cidade de Évora (Portugal). Da autoria do fotógrafo português Jerónimo Heitor Coelho, o livro foi galardoado em 2015 com a atribuição do "Prix de la Littérature Gastronomique" pela Academia Internacional de Gastronomia (Paris) ${ }^{3}$. A complementar os resultados da análise qualitativa de conteúdo juntam-se excertos de uma entrevista presencial, realizada pela investigadora ao fotógrafo e autor em Setembro de $2014^{4}$.

Évora é uma cidade de média dimensão, com aproximadamente 50.000 habitantes, localizada na região Alentejo, no sul de Portugal. O Centro Histórico de Évora é um espaço intramuros, classificado como Património Mundial pela UNESCO desde 1986. A cidade, cuja história recua mais de cinco milénios, tem um passado e entorno rural recente que a torna particularmente apelativa no quadro da "gastronomia alentejana", uma das várias expressões reconhecidas da cozinha típica portuguesa. Prova disso é a proliferação recente de espaços de restauração (SIMPLÍCIO; CAMELO, 2015), como também a organização de diversas iniciativas de promoção gastronómica d(n)a cidade. Eventos como a «Rota de Sabores Tradicionais»e «Doze Meses de Boa Mesa» contaram com várias parcerias institucionais locais, ao mesmo tempo que agregaram restaurantes e pastelarias (com fabrico próprio) do concelho de Évora, por vezes também lojas gourmet, no compromisso de oferecer os pratos característicos da região, elaborados a partir do receituário tradicional das sopas, carnes de porco, borrego, caça e doçaria conventual, ao longo de um determinado período temporal. Paralelamente, estas edições incluíram um programa variado de animação, com destaque para a realização de seminários, visitas

\footnotetext{
${ }^{2}$ Comer em Évora: os restaurantes e as suas receitas = Eat in Évora $:$ the restaurants and their recipes / Jerónimo Heitor Coelho; textos Francisco Bilou, Francisco Santos; rev. texto Francisco Bilou; trad. Michael W. Lewis. $1^{\text {a }}$ ed = 1st ed. - [S.1.]: Visual Factory, 2014 ([Mem Martins]: Printer Portuguesa). - 208, [8] p. a 2 colns, 16 p.: il. ; 27 x $30 \mathrm{~cm}$. - Ed. bilingue em português e inglês. - ISBN 978-989-98772-1-4 (cf. referência completa em url: http://bibliografia.bnportugal.pt/bnp/bnp.exe/registo? $\mathrm{mfn}=27797$, consulta a 2017-10-05).

${ }^{3}$ A Académie Internationale de la Gastronomie (AIG) é uma rede transnacional fundada em 1983. URL: http://www.intergastronom.net

${ }^{4}$ A entrevista decorreu a 1 de Setembro de 2014 no estúdio do fotógrafo, em Évora. Nos excertos da transcrição apresentados adiante "E" significa Entrevistadora e "JHC" são as iniciais do fotógrafo.
} 
temáticas e outros eventos enogastronómicos. À escala da freguesia, a «Prova de Vinhos, Sopas, Doces, Compotas e Licores», organizada pela Casa do Povo de Canaviais, tem ocupado um lugar de destaque, não apenas pela regularidade da organização, atualmente na 14. ' edição, mas sobretudo pelo envolvimento da população local, não profissional, que ano após ano vê o seu saber-fazer reconhecido e premiado nas cinco categorias a concurso.

Sem retirar o devido valor - e interesse sociológico - à análise de tais eventos, a que se poderiam juntar inúmeros outros de semântica afim (e.g. festivais, feiras e festas de sabores, concursos e mostras gastronómicas), este texto envereda por outro caminho: toma como objeto de estudo principal um livro. Os livros, na sua materialidade aparentemente anódina, revelam muito acerca da sociedade que os produz. A literatura enogastronómica não constitui exceção. Olhar à sua forma, conteúdo, aos seus autores e destinatários constitui um exercício complexo, necessariamente imbricado em coordenadas espácio-temporais, sobretudo, culturais. Efectivamente, todos os livros têm um valor simultaneamente histórico e social que os torna objetos de cultura (BRIEN; WESSELL, 2013; COSTELLO, 2013; JOHNSTON; BAUMANN, 2007). E se é certo que podem ser vistos como repositórios de informação, logo, de memória; certo é que podem também ser explorados na relação entre a informação que contêm e o que esse conteúdo reflete sobre a cultura em sentido mais amplo, neste caso, os processos e técnicas de produção, transformação, distribuição, preparação, apresentação e consumo alimentar, assim como os valores que enformam tais práticas culturais.

O livro Comer em Évora: os restaurantes e as suas receitas, publicado em versão bilingue português - inglês, assume claramente uma vocação de apresentação e promoção turística de Évora do ponto de vista enogastronómico ${ }^{5}$. Na aba do livro o autor apresenta a obra precisamente como um misto de registo histórico e instrumento de promoção da cidade:

Este projeto nasceu de um genuíno desejo pessoal que sempre julguei possível
materializar: o de dar a Évora um livro que honrasse a cidade e a sua cultura
enogastronómica. Decerto um livro documental, onde os saberes e os sabores
se revelassem através da fotografia dos espaços de restauração, dos produtos
aí confecionados e servidos, fixando nele os rostos, tantas vezes anónimos, dos
seus exímios criadores...
A obra foi nascendo, fotografa a fotografia. E as páginas adensaram-se de
histórias, de vivências, de paixões, de sorrisos. Em poucos meses fechou-se

\footnotetext{
${ }^{5}$ Não obstante, o projeto de edição do livro foi desenvolvido sem recurso a qualquer financiamento ou subsídio para o efeito. De acordo com declarações do autor, na entrevista já citada, a forma encontrada para financiar o projeto assentou num modelo adaptado de "crowdfunding", através do qual os estabelecimentos aderentes acordaram na aquisição antecipada de um determinado número de exemplares.
} 
um círculo de cumplicidades. Tudo somado, o projeto acabou por assumir a enorme responsabilidade de fixar na memória da minha geração a visualidade de um tempo acabado de testemunhar. É com essa responsabilidade que agora o assumo enquanto autor: como registo documental e artístico, datado e assinado, não só para exibir como «peça de valor» do nosso património cultural, mas, sobretudo, para promover em qualquer parte do mundo o que de melhor a cidade e a região têm para oferecer a quem as visita ou as queira visitar (COELHO, 2014, s.p.).

Uma forte e assumida combinação entre narrativa textual e visual caracteriza este livro. Como sublinha Galopim de Carvalho ao prefaciar a obra: "De distinta craveira na arte e na tecnologia fotográficas, o autor concebeu uma obra focada na gastronomia local, de invulgar excelência no discurso e, em especial, nas imagens [...]" (GALOPIM DE CARVALHO, 2014, p. 7) ${ }^{6}$. Já o autor, admitiu em entrevista7 tratar-se de um "livro de fotógrafo" que não mostra "só um restaurante", mostra também "mais qualquer coisa": a cidade, o que a cidade pode oferecer e por quem:

E: Como é que surgiu a ideia de fazer este livro?
JHC: A ideia de partir para este livro foi querer mostrar mais qualquer coisa,
do que é que é a cidade e do que é que ela pode oferecer em termos turísticos
e em termos pessoais. Repare, eu sou fotógrafo. Ponto. Não quero, não tenho
pretensões a ser mais do que isso [...] Em termos de construção ele [o livro]
foi ganhando forma porque eu achava, sempre achei que era importante... Uma
das minhas áreas de especialidade é a arquitetura de interiores. Repare, e
mostrar os restaurantes de uma forma diferente, com luzes diferentes, com uma
forma em termos de abordagem diferente... Outra das áreas em que eu tenho
algum reconhecimento é a questão do retrato, e eu sempre o quis colocar
porque acho que é importante mostrar as pessoas. Porque normalmente as
pessoas passam despercebidas, e neste tipo de atividades o produto final
obrigatoriamente passa por pessoas. Aquilo que nos chega à mesa passa por
pessoas e nós quando vamos a um restaurante, fazer uma refeição, ou simples
ou de amigos, ou um convívio, não damos valor a quem está por detrás e a
quem preparou tudo aquilo. E a finalidade foi mostrar efetivamente as pessoas
que estão por detrás. E acho que é extremamente importante nós conhecermos
quem é que dá corpo a esta... ou seja, dar-lhes o devido mérito por aquilo que
eles fazem. E estamos a falar de empresas familiares que se desenvolvem ao

${ }^{6}$ Refira-se todavia que não se faz aqui qualquer análise do ponto de vista da qualidade técnica das fotografias, aspeto que extravasaria quer o propósito do artigo, quer a competência da autora. Essa qualidade é tão-somente atestada, por um lado, pelo prefaciador; por outro, pelo próprio fotógrafo. Efetivamente, no decorrer da entrevista o fotógrafo enfatizou por diversas vezes a exigência e qualidade técnica associada às fotografias incluídas no livro, seja a fotografia de mesa, do prato confeccionado ou dos ingredientes base da gastronomia alentejana. Como refere: "[...] isso foi uma das coisas que eu sempre quis fazer, foi fotografar uma mesa desses restaurantes, ou seja, com aquilo que eles servem mas fotografado dentro do próprio ambiente. É uma fotografia técnica mas muito complexa em termos de execução, por causa de todas as iluminações, de todo o processo que envolve a concessão de uma imagem destas. [...] Depois, quis introduzir uma receita do próprio restaurante, já uma fotografia feita no próprio espaço também mas já com um ambiente de iluminação completamente diferente em ambiente de estúdio, perfeitamente controlado. [...] e colocar os ingredientes de base da gastronomia alentejana. Todos fotografados dentro do mesmo conceito. Repare, por exemplo este caso que nós estamos aqui a ver da perdiz [aponta no livro], foi tudo fotografado aqui no estúdio. O borrego foi fotografado no estúdio, o porco foi fotografado no estúdio. Portanto, a ideia foi fazer o mesmo conceito de fotografia, das naturezas mortas, ou seja, dos produtos, mas os produtos vivos, eu quis fotografá-los vivos, no mesmo ambiente e com o mesmo tipo de iluminação, com a mesma situação. Foi dar o mesmo look e a mesma aparência em termos de imagem [...]”.

${ }^{7}$ Entrevista realizada em 1 de Setembro de 2014, conforme explicitado adiante na secção dedicada à metodologia. 
longo de muitos anos e que... não é só um restaurante, há mais qualquer coisa. É um restaurante mas que tem pessoas e que lida com pessoas todos os dias e a finalidade basicamente foi essa, foi mostrar a cidade, mostrar o que é que a cidade pode oferecer dentro desta área gastronómica e por quem é que pode oferecer.

Precisamente porque um livro é um produto cultural, pensado, desenhado e (re)discutido até chegar à sua versão final, interessa perceber de que modo é também um produtor de cultura. Como são apresentados os restaurantes de Évora ao leitor e eventual consumidor? Que histórias se contam? Que imagens são escolhidas? O que revelam os textos sobre esses espaços? E o que ocultam? Quem são os protagonistas selecionados para dar rosto aos restaurantes? E em que poses são apresentados ao leitor? No conjunto, que valores são invocados? Em suma, como é que um livro, este livro em particular, pode contribuir para compreender os modos através dos quais a literatura enogastronómica contribui para a (re)construção social de Évora como lugar e destino turístico? Sem querer entrar no domínio específico da técnica fotográfica, do retrato ou da escrita literária, este texto dá a conhecer uma incursão exploratória sobre a análise das estratégias discursivas que no domínio particular da enogastronomia são mobilizadas para a (re)construção social de lugares e identidades, sempre na relação entre "nós" e "os outros".

\section{Turismo, identidade e consumo enogastronómico. Ainda "nós" e "os outros", "anfitriões" e "convidados"}

Fenômeno social total, que encerra múltiplas dimensões como a fisiológica, psicológica, ecológica, económica, religiosa, política, social e cultural, a alimentação é um tópico tão (ainda) invisível quanto profícuo para a investigação e análises sócio antropológicas (LÉVI-STRAUSS, 1965; BEARDSWORTH; KEIL, 1997). Das práticas de alimentação em comunidade ou em família ao "comer fora", à sociologia interessam todos os processos envolvidos na produção, distribuição, preparação, apresentação e consumo de alimentos.

São dois os enfoques principais que a sociologia tem colocado sobre o estudo da alimentação (BEARDSWORTH; KEIL, 1997). De um lado, afirma-se o interesse por analisar a produção, o consumo e, sobretudo, a estrutura social e as relações que lhe são subjacentes, nomeadamente os mecanismos de diferenciação social como o género, idade, classe e suas consequências na organização (des)igual da vida quotidiana. A análise dos fundamentos e mecanismos de distinção social e gosto estudados inicialmente por Bourdieu, seguido por outros, são porventura um dos exemplos mais icónicos neste 
domínio (BOURDIEU, 1979; GRONOW, 1997; KORSMEYER, 2005; SOUTHERTON, 2006; WARDE, 1997, 2005). De outro lado, avolumam-se os estudos que tomam os tópicos relacionados com a alimentação como um fim em si mesmo. Especificamente, são alvo de análise particular as questões relacionadas com o "[...] como obtemos, partilhamos, selecionamos, preparamos e ingerimos os alimentos, e como atribuímos significado ao que estamos a fazer" (BEARDSWORTH; KEIL, 1997, p. 5). Inscrevemse neste domínio os estudos que incidem de forma particular sobre as coordenadas socioculturais que ajudam a compreender o lugar do consumo como marca distintiva do individualismo contemporâneo (BAUMAN, 2007; CHANEY, 1996; FEATHERSTONE, 1991; GABRIEL; LANG, 1995; MILLER, 1996).

Nos últimos anos tem-se registado um interesse crescente pelo turismo enogastronómico, tanto no contexto da oferta quanto da procura/consumo. Concomitantemente, tem-se assistido à emergência e afirmação das gastronomias locais ou "patrimónios gastronómicos regionais" (POULAIN, 2002), os quais traduzem uma progressiva patrimonialização das culturas alimentares tradicionais. $\mathrm{O}$ contacto com culturas alimentares locais ou tradicionais é motivado por causas diversificadas, como seja a busca por uma experiência excitante, escape à rotina, preocupações com a saúde, busca de conhecimento, procura de uma experiência autêntica, experiência de um sentimento de união, prestígio, apelo sensorial ou encontro com o ambiente natural, causas essas atravessadas por fatores de natureza fisiológica e, sobretudo, demográfica, nomeadamente o género, a idade e as habilitações literárias (KIM; EVES; SCARLES, 2009).

A montante deste processo discute-se a importância da enogastronomia como instrumento de contacto com a cultura e identidade de um outro povo que se visita ou com o qual se toma contacto. Utilizado este argumento para efeitos de segmentação de mercado, planifica-se e ajusta-se a oferta de modo que, a jusante, o turista/consumidor possa imergir nessa cultura. Estudos desenvolvidos nesta área demonstram que a motivação para viajar por razões relacionadas com a gastronomia é importante (HALL et al., 2003). A gastronomia local é não apenas um dos fatores que ajuda a compreender a satisfação perante a viagem, ou seja, o modo como os turistas avaliam a experiência no destino (SILKES; CAI; LETHO, 2013), como pode também ser utilizada enquanto ferramenta ao serviço do turismo sustentável (SIMS, 2009), ou ainda para compreender os motivos de regresso a destinos antes visitados (KIVELA; CROTTS, 2005). 
Portugal tem vindo a afirmar-se como um importante destino turístico no contexto da Europa Meridional e Mediterrânica, facto comprovado pelos aumentos significativos de procura (UNWTO, 2017). No caso particular do turismo enogastronómico, são várias as evidências que parecem sustentar o consenso em torno da importância estratégica de afirmação da gastronomia como património cultural a capitalizar para o sector do turismo (SARAMAGO, 2002). Por um lado, este produto tem registado um crescimento anual de $5 \%$ a $8 \%$ desde 2000 , valores que se perspetivam poder situar-se nos $8 \%$ a $10 \%$ nos próximos anos (TURISMO DE PORTUGAL, 2013). Por outro, o Plano Estratégico Nacional do Turismo, na revisão e objetivos que traçou para o período 2013-2015 previa um projeto específico (17), desenvolvido com o propósito de enriquecer a experiência turística por via da gastronomia e vinhos nacionais. O fundamento era o de que "[a] qualidade e diversidade da gastronomia e vinhos nacionais potenciam uma oferta distintiva para o turista que visita Portugal. Nesse sentido, devem assumir um papel importante no enriquecimento da experiência do turista" (TURISMO DE PORTUGAL, 2013, p. 57). As atividades aí previstas tinham em vista criar e promover um referencial de utilização da marca «Prove Portugal»; sensibilizar os produtores/industriais agroalimentares para formatarem rotinas de visitação/usufruto turístico complementares à sua atividade principal; incrementar a qualificação dos serviços na restauração, ao nível da valorização dos produtos e receituário regionais e da melhoria dos serviços de cozinha e sala no âmbito do «Prove Portugal»; desenvolver roteiros enogastronómicos suportados nos recursos distintivos das regiões, envolvendo produtores e prestadores de serviços; e promover internacionalmente os produtos de excelência e os chefes, no âmbito do «Prove Portugal». Concretamente no que diz respeito à Região Alentejo, este mesmo plano defendia que o produto reúne condições para aí se autonomizar e criar afluência específica para a região. Não obstante, “[...] verifica-se a necessidade de desenvolver roteiros enogastronómicos, densificar atividades, desenvolver conteúdos e experiências e integrar a oferta em plataformas de promoção e comercialização" (TURISMO DE PORTUGAL, 2013, p. 35).

Acompanhando de perto o acréscimo turístico registado no país, também as visitas à cidade de Évora têm aumentado nos últimos anos (MARUJO; SERRA; BORGES, 2012). A par da dimensão histórica e patrimonial da cidade classificada património mundial pela UNESCO em 1986, principal motivação para visitar a cidade de Évora, a cozinha regional e os vinhos atraem um número considerável de turistas à cidade (BORGES; SERRA; MARUJO, 2013; AMARAL et al., 2016). Este facto é aliás 
reconhecido na estratégia de desenvolvimento do sector para a região (TURISMO DE PORTUGAL, 2006 e 2013).

A "gastronomia alentejana" constitui uma das várias expressões reconhecidas da cozinha típica portuguesa (QUITÉRIO, 1994). De acordo com Amaral et al., (2016), o conhecimento sobre a gastronomia alentejana por parte de turistas internacionais é reduzido, ainda assim a expectativa é elevada, o que faz com que a gastronomia funcione como um fator de atratividade importante. Não será, todavia, longa esta tradição. Segundo Francisco Bilou, “[...] a oferta gastronómica de tradição rural nos restaurantes de Évora não tem mais antiguidade do que as três últimas gerações de profissionais de restauração" (BILOU, 2014, p. 13).

No que respeita à gastronomia alentejana, a diferença entre "nós" e "os outros" ou entre "anfitriões" e "convidados" (SMITH, 1977) afirma-se, desde logo, pelo contacto com a cozinha tradicional, própria de uma região de fracos recursos, e que precisamente por isso pode ser ponto de (re)encontro em tempos de crise. Como afirma Galopim de Carvalho ao prefaciar a obra:

Hoje, nos tempos de crise que se instalaram, a cozinha alentejana reencontra expressão ao lembrar que, com simples produtos da terra, bravios ou cultivados, é possível confecionar saudáveis e apetitosos "comeres". Com tais recursos, os alentejanos criaram e desenvolveram uma cozinha única, nutritiva, saborosa e agradavelmente perfumada. (GALOPIM DE CARVALHO, 2014, p. 8)

Por outro lado, essa diferença acentua-se pela "qualidade e autenticidade da cozinha tradicional alentejana" (BILOU, 2014, p. 13). O historiador Francisco Bilou enaltece assim a persistência de uma cozinha pobre, que reflete historicamente as condições duras de interioridade, isolamento e sobrevivência dos assalariados agrícolas numa região de parcos recursos. A cozinha alentejana resulta, em grande medida, de uma combinação histórica e criativa entre esses produtos da terra, bravios ou cultivados, pão e ervas aromáticas. Acresce que esta combinação não surge no vazio, antes num contexto sócio-cultural tradicionalmente imbricado com o ciclo anual da natureza, a vida eclesiástica e conventual da cidade. De acordo com este historiador, a generalização do gosto pela cozinha alentejana de raiz popular e camponesa é relativamente recente e devese à conjugação de três fatores principais:

[...] a "democratização" da mesa como "conquista social" (particularmente da classe média surgida, sobretudo, após a revolução de 1974); a aceitação da "ruralidade" como fator de identidade cultural e de diferenciação da oferta turística (sobretudo a partir da década de oitenta do século passado); a "individualização" clara de um receituário rural alentejano apropriado por mestres cozinheiros, recriado e divulgado a partir de espaços seletos de restauração (de que os irmãos Fialho e o seu restaurante homónimo são 
referência histórica incontornável, mas onde se não deve esquecer o pioneirismo das Pousadas de Portugal neste particular) (BILOU, 2014, p. 13).

Justamente porque a motivação para o consumo enogastronómico parece advir de uma certa busca pela "tradição", pelo "autêntico" e "típico", interessa compreender o modo como objetos culturais específicos organizam e apresentam discursivamente os elementos que alicerçam tal montra.

\section{Notas metodológicas: folhear, entrevistar e analisar}

Os trabalhos de John Urry nos anos 90 (URRY, 1990, 1995) parecem ter sido determinantes para um enfoque crescente no visual e na visualidade em estudos de turismo (PALMER, 2009; RAKIĆ; CHAMBERS, 2012; SCARLES, 2010), enfoque esse que acompanha uma tendência generalizada no domínio da investigação qualitativa (PINK, 2001, BANKS, 2007, ROSE, 2001). Tijana Rakić e Donna Chambers advogam pela existência de três formas principais através das quais os métodos visuais podem ser utilizados em pesquisas sobre turismo: quando recolhidos através de fontes secundárias e posteriormente analisados por meio de técnicas como a análise de conteúdo ou semiótica; criados propositadamente para efeitos de investigação, seja pelos investigadores, seja por participantes na investigação; e, por fim, utilizados para gerar dados através de técnicas de elicitação. Centrado na análise em profundidade de uma fonte secundária - o livro Comer em Évora: os restaurantes e as suas receitas (cf. Figura 1) - este trabalho inscreve-se claramente na primeira abordagem.

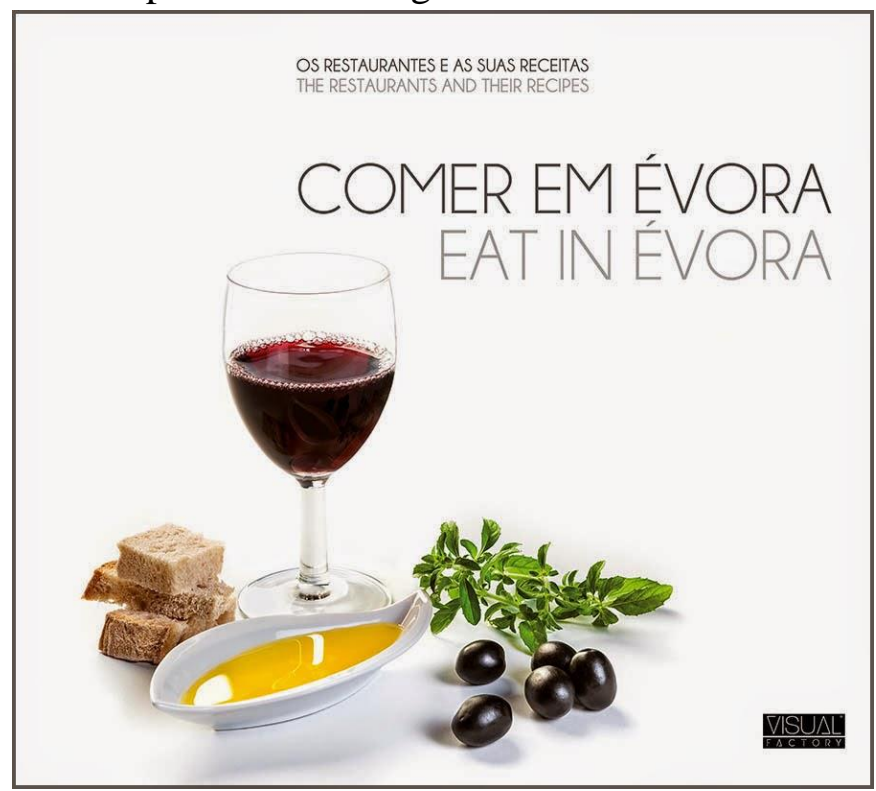

Figura 1: Capa de Comer em Évora: os restaurantes e as suas receitas

Fonte: Imagem retirada da página de facebook de Jerónimo Heitor Coelho Photographer, perfil público disponível em url: https://www.facebook.com/JHCPhotographer (acesso em: 10 jun. 2017) 
Em complemento aos argumentos aduzidos na introdução a este texto, o recurso a informação disponível a partir de fontes secundárias, assim consideradas porque aqueles que as criaram não estão envolvidos no processo de pesquisa, justifica-se por duas razões adicionais, para as quais chamam a atenção Saala Jokela e Pauliina Raento (2012). Por um lado, para além de disponível, é também uma fonte "student - and teacher friendly" (JOKELA; RAENTO, 2012, p. 54), de custo e dimensão reduzida, o que a torna facilmente acessível. Por outro lado, há uma contiguidade entre objeto e objetivos de estudo, já que parece ser consensual que grande parte da informação que subjaz ao processo de decisão do comportamento do turista assume justamente a forma visual (JOKELA; RAENTO, 2012). É certo que dados desta natureza “[...] contam histórias únicas, para cada lugar, país, ou empresa" (JOKELA; RAENTO, 2012, p. 53). Precisamente também por isso ajudam a compreender a especificidade do contexto mais amplo em que se processa a construção de um lugar turístico, no caso particular, os modos através dos quais a literatura enogastronómica contribui para a (re)construção social de Évora como lugar e destino turístico.

De modo complementar foi realizada uma entrevista presencial, de tipo semiestruturada (FLICK, 2005), com o autor do livro, Jerónimo Heitor Coelho, em 1 de Setembro de $2014^{8}$. O recurso à entrevista vem corroborar uma característica adicional dos métodos visuais, raramente utilizados de forma independente de outros métodos não visuais (RAKIĆ; CHAMBERS, 2012).

Os dados recolhidos foram analisados com recurso a técnicas de análise qualitativa de conteúdo, particularmente análise categorial e análise do discurso. Para o efeito seguiram-se fundamentalmente as orientações metodológicas propostas por Laurence Bardin (1977) e Klaus Kripendorff (2003). No caso particular da análise visual, acompanharam-se de perto as propostas de Tony Shirato e Jen Webb (2004) tendo em vista uma "leitura" do visual. Nesta abordagem, os objetos não são apenas para ser vistos, contêm uma história, ou um conjunto de informações, às quais podemos aceder, do mesmo modo que podemos aceder ao conteúdo de um texto escrito (SHIRATO; WEBB, 2004). O estudo destas narrativas deve contemplar tanto o que é contado como o próprio processo de contar e as estratégias utilizadas para tal. Assim, a análise narrativa deverá preocupar-se em identificar o enredo, narrador, personagens, eventos, tempo, espaço e

\footnotetext{
${ }^{8}$ No total a entrevista durou 00:35:39 minutos. Mediante autorização prévia, a entrevista foi gravada em suporte áudio e posteriormente transcrita com recurso a Express Scribe Transcription Software v 5.74 $(\mathrm{NCH} \circledast$ Software).
} 
relações causais (SHIRATO; WEBB, 2004). Ao atentar ao detalhe da narrativa, especificamente à parte tangível do seu conteúdo (palavras, expressões, metáforas, imagens), a análise efetuada aproxima-se de uma análise de tipo storytelling (KLANTEN; EHMANN; SCHULZE, 2011). Neste contexto, o objetivo passa não apenas por analisar a "história" que é narrada (story), mas também investigar os modos como é narrada ao leitor/consumidor (telling).

Para a apresentação de resultados optou-se pela reconstrução textual de narrativas contextualizadas (FLICK, 2005). A narrativa contextualizada aproxima os dados das experiências e do contexto que os gera e procura daí retirar o sentido interpretativo mais amplo. Para o leitor resulta a apresentação da informação de uma forma fluida, onde a interpretação surge mesclada com citações verbatim retiradas tanto do livro quanto da entrevista e incluídas no corpo do texto sem que dele se autonomizem necessariamente.

\subsection{Forma e estrutura: layout e corpus de análise}

O livro Comer em Évora: os restaurantes e as suas receitas faz referência a 32 restaurantes e espaços de promoção e venda de produtos regionais estabelecidos na cidade de Évora. Os espaços de promoção contemplam garrafeiras, lojas gourmet, pastelarias e outros locais de venda de pão, vinho e diversos produtos locais. A apresentação destes espaços é intercalada em página ímpar por fotografias e descrições de produtos regionais, nomeadamente, pão; ervas aromáticas (e.g. alecrim, tomilho, orégãos, hortelã, salsa, coentros, poejos, hortelã da ribeira, salva, louro e escorcioneira); plantas selvagens (e.g. espargos, túberas, beldroegas, silarcas, poejos, catacuzes, acelgas); aves (e.g. aves de capoeira e caça), peixe e animais (e.g. borrego, porco e caça de pelo); produtos "alémmar”, azeite, vinho e produtos transformados como queijos e enchidos. Em página par são as fotografias de património da cidade e paisagem envolvente que servem de separador.

A análise aprofundada que foi efetuada tomou como corpus de análise exclusivamente o conjunto de restaurantes referenciados no livro (23), isto é, os estabelecimentos cuja principal oferta contempla o serviço de refeições completas (entradas, pratos principais e sobremesas). No conjunto da obra, a apresentação de cada um dos restaurantes segue uma formatação idêntica, apoiada num layout que se estende ao longo de quatro páginas (cf. Figura 2). Na primeira página (par) são apresentadas fotografias do espaço da sala de refeições em número que pode variar de duas a quatro, é 
indicado o nome do restaurante, logotipo (caso exista) e uma pequena descrição do mesmo (em português e inglês) com indicação das "Especialidades" respetivas. Na segunda página (ímpar) uma fotografia de mesa ocupa toda a mancha de página. Deste modo, o leitor pode observar a "mesa posta", com o melhor que o restaurante tem para expor, ao mesmo tempo que imagina aquela mesa no cenário mais vasto do restaurante que encontra fotografado e descrito à esquerda. Segue-se, na página par seguinte (página 3), uma receita selecionada de entre as especialidades do restaurante. A descrição é feita em língua portuguesa e inglesa e acompanhada da respetiva fotografia em baixo. Por fim, a quarta e última página (ímpar) apresenta uma fotografia do(s) rosto(s) por detrás do restaurante. Esta fotografia, legendada em baixo com os nomes do(s) visado(s), vem acompanhada de um pequeno texto de enquadramento, fornecido pelos próprios estabelecimentos". A página deixa ainda espaço para "A nossa Mensagem | Our Message", onde o próprio cliente pode tomar nota da experiência no local. Por fim, apresentam-se os contactos do restaurante, designadamente nome, morada postal, contacto telefónico, endereço web e coordenadas GPS.

Página 1 [Par]

Página 2 [Ímpar]

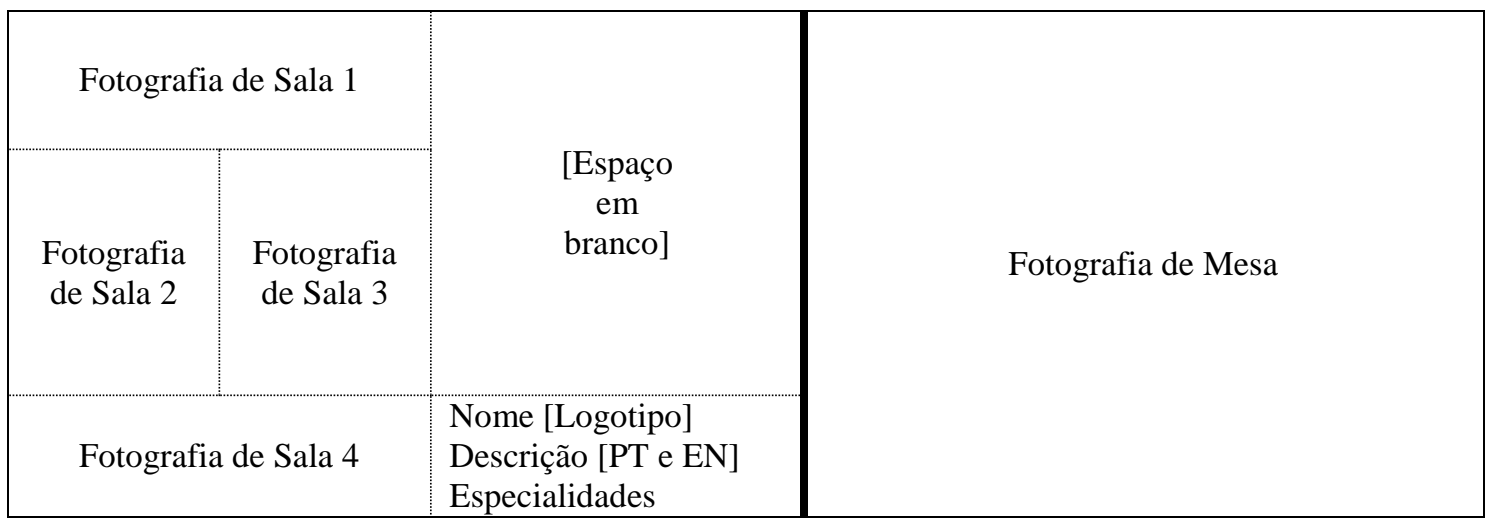

Página 3 [Par]

Página 4 [Ímpar]

\begin{tabular}{|c|c|c|c|}
\hline Receita [PT] & Receita [EN] & Texto & $\begin{array}{c}\text { Fotografia } \\
\text { [com indicação dos } \\
\text { nomes] }\end{array}$ \\
\hline \multicolumn{2}{|c|}{ Fotografia do prato } & \multicolumn{2}{|c|}{$\begin{array}{c}\text { A nossa Mensagem | Our Message } \\
\text { [Espaço em branco }]\end{array}$} \\
\hline
\end{tabular}

\footnotetext{
${ }^{9}$ Conforme informação prestada pelo fotógrafo, em entrevista a 01-09-2014.
} 


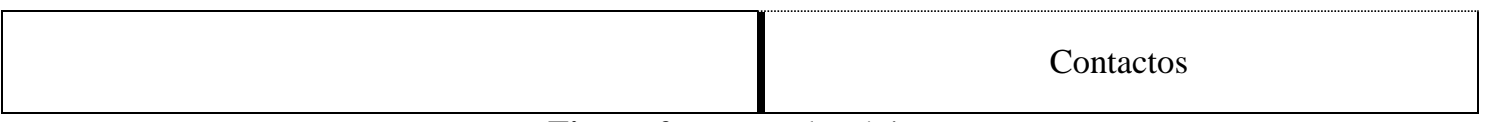

Figura 2: Layout de página

Fonte: Elaboração própria

\subsection{Conteúdo e sequência: da leitura flutuante ao modelo de análise}

A obra Comer em Évora agrega um conjunto variado de estabelecimentos relacionados com a restauração e atividades afins. Apesar de não haver consenso quanto a um sistema de classificação para os estabelecimentos de Alimentos e Bebidas (A\&B), um dos caminhos possíveis para a análise de dados teria sido a definição a priori de categorias, nomeadamente, as que se relacionam com a qualidade do serviço prestado (de luxo, primeira, segunda categoria, etc.); com aquilo que é servido (restaurante, lancharia, confeitaria, sorvetaria ou bar); a relação entre o cliente e a prestação do serviço no sentido de como se serve (a la carte, menu fixo ou empratado, self-service, buffet, a quilo, balcão, drive-thru) ou ainda a especialidade (neste caso apenas aplicável a restaurantes, nomeadamente, se cozinha internacional, cozinha típica nacional, cozinha típica regional, cozinha caseira, cozinha natural/light, churrascaria, pizzaria, hamburgueria, etc.).

Dada a natureza exploratória do estudo em questão, em alternativa a uma análise de procedimento fechado optou-se por empreender uma análise de procedimento aberto, de base indutiva e alinhada com os pressupostos da grounded-theory (GLASER; STRAUSS, 1967). Deste modo, após uma análise exploratória e leitura flutuante inspirada pelas orientações metodológicas subjacentes à análise de narrativas visuais (SHIRATO; WEBB, 2004) e storytelling (KLANTEN; EHMANN; SCHULZE, 2011), estabilizou-se o modelo de análise com base na identificação de três eixos principais e seis secundários (cf. Figura 3).

\begin{tabular}{|l|l|}
\hline \multirow{2}{*}{ Eixos de análise } \\
\hline Principais & Secundários \\
\hline Cenário & $\begin{array}{l}\text { Espaço (localização, origens, história) e } \\
\text { ornamentação da sala }\end{array}$ \\
\cline { 2 - 2 } & Disposição e guarnição da mesa \\
\hline Protagonistas & Rostos fotografados \\
\cline { 2 - 2 } & $\begin{array}{l}\text { Natureza da relação entre protagonistas e } \\
\text { proprietários }\end{array}$ \\
\hline Guiões & Especialidades selecionadas \\
\cline { 2 - 3 } & $\begin{array}{l}\text { Descrição narrativa do espaço (valores, } \\
\text { metáforas) }\end{array}$ \\
\hline
\end{tabular}

Figura 3: Eixos e dimensões de análise

Fonte: Elaboração própria. 
Para a definição dos eixos e dimensões de análise foi particularmente relevante a entrevista realizada com o fotógrafo. Dessa entrevista emergiu indutivamente a ideia de mise-en-scène do livro Comer em Évora, qual montagem ou encenação que resulta da junção de um espaço concreto e pessoas definidas captados pela lente de um fotógrafo que (sabe) não é inócuo. Ao montar a cena que fotografa o fotógrafo é construtor indelével de uma realidade, desde logo no que à mesa diz respeito:

E: Como é que se chegou a esta mesa?

JHC: Isto [a mesa] é-nos apresentado pelos donos do espaço, o que é que têm [...]

E: O que é que lhes foi pedido?

JHC: O que é que vocês fazem, o que é que vos identifica, por que é que vocês são conhecidos pelos vossos clientes em termos de gastronomia? Sem limites, sem restrições. Repare, eu tive mesas enormes, tive mesas pequenas, portanto, tudo tem a ver com o conceito do espaço e com aquilo que o espaço nos diz. Foi o chef ou o cozinheiro que definiram o quê. Depois a forma de arranjar os produtos... já é da minha responsabilidade. A forma de os colocar na mesa, o ângulo, o local, isso aí já é tudo da minha responsabilidade. O cenário foi todo composto por mim, sim. A colocação deste objeto aqui [aponta no livro], para não ficar aqui um espaço em vazio, o próprio virar da cadeira para me dar aqui um ângulo de fechar a imagem, repare, são todos pequenos pormenores que, portanto..., que têm a ver com a composição de imagem. Começa pela escolha do local [...] São uma série de anos de experiência e a habituação que eu fui criando no meu interior, a forma de sentir e de ver as coisas... que as coisas saem com naturalidade. Ou seja, isto não... eu não tenho que andar a estudar, a ver se..., não. Vou vendo, vou colocando, vou alterando, em função da minha sensibilidade interior, daquilo que eu acho que se torne mais, mais harmonioso e com mais impacto visual e que transmita melhor a mensagem daquilo que eu pretendo. $[\ldots]$

E: Mas estes elementos, eram todos elementos que existiam no restaurante?

JHC: Sim, sim, sim. Estavam aqui em cima do balcão expostos [aponta no livro] e eu fui colocando à medida na mesa, de forma... portanto, os menos redondos, portanto... para me dar esta questão da dimensão, dar-me estas linhas, os pratos maiores. Criando também aqui alguma harmonia em termos do que são pratos principais, do que são os pratos secundários, ou as entradas, e depois colocando os pontos de mais, mais... epá, por exemplo, o pão, porque é que está nesta zona? Porque está numa zona mais clara em cima duma zona mais escura e não está aqui a tapar as garrafas. Epá, são pequenos pormenores mas que me saem assim, nem consigo ver doutra maneira. [...]

\section{O mesmo princípio de encenação extravasa para o domínio do retrato:}

E: E em relação aos retratos? Quem escolheu as pessoas?

JHC: As pessoas são sempre os representantes e são sempre as pessoas que dão a cara pelo restaurante. Portanto, ou a pessoa... ou o dono mesmo, ou a pessoa que está na cozinha, o chef ou o cozinheiro, como por vezes se intitulam, quando não se querem intitular como chefs. Para eles são simples cozinheiros. Ou um misto, que é o caso, este é o dono e é o cozinheiro, é o chef [aponta no livro]. Agora, a forma, o local, o contexto, isso já é da minha responsabilidade.

A terminar esta nota metodológica, espaço ainda para um breve apontamento de natureza ética. $\mathrm{O}$ recurso a metodologias visuais não coloca questões substancialmente diferentes das suscitadas na generalidade dos processos de investigação científica. Como 
afirma Prosser (1998), também em estudos visuais as questões éticas são sempre contestadas, dinâmicas e contextuais. No caso particular da análise aqui empreendida, os restaurantes analisados foram codificados numérica e sequencialmente a partir da ordem por que são apresentados no livro. Isto significa que o leitor em posse da obra pode, a qualquer momento, identificar o restaurante em causa e ajuizar da pertinência das referências e associações que são feitas ao longo deste texto, sua consistência e validade. Quanto às referências feitas aos espaços de restauração, inclusive as citações extraídas das descrições respetivas, em caso algum permitem uma identificação direta e imediata. No caso da fotografia, e porque esta compromete fortemente o anonimato (RAKIĆ; CHAMBERS, 2012) foi opção refletida não incluir qualquer reprodução no corpo do texto. Paralelamente, foram propositadamente ocultadas todas as referências explícitas à designação dos espaços, instituições ou indivíduos citados ${ }^{10}$. Em suma, porque as conclusões a retirar do artigo interessam a uma audiência internacional e diversificada, preterimos explicitamente a identificação dos espaços em prol da desocultação das estratégias discursivas mobilizadas para a prossecução dos fins visados.

O conjunto de textos e imagens que compõem a apresentação dos 23 restaurantes que integram o corpus de análise foi codificado sistematicamente a partir dos eixos de análise e posteriormente submetidos a um processo de comparação constante, de acordo com as práticas usualmente adotadas em procedimentos de análise qualitativa de conteúdo (COSTA, 2015). Por fim, os dados foram agrupados em três categorias principais, as quais resultaram parcialmente designadas de forma indutiva a partir da codificação in vivo e que a seguir se detalham: "A autenticidade da "boa mesa" alentejana"; "De geração em geração, o segredo da cozinha alentejana"; "A reinvenção da cozinha alentejana, e os sentidos aqui tão perto".

\section{4 "Comer em Évora: os restaurantes e as suas receitas"}

\subsection{A autenticidade da "boa mesa" alentejana}

O cenário é quase sempre o de um antigo espaço ligado à restauração ou ao manuseamento de produtos alimentares. Estes espaços apropriam-se de uma "semântica do vinho e da taberna" (RAMOS, 2010, p. 39), que utilizam para legitimar a antiguidade no ramo. Sucederam ou herdaram espaços aos quais mantêm ligação por meio de uma tradição que se perde na memória do tempo, porque imbricada com a história da cidade e

${ }^{10}$ Os caracteres [\#\#\#] foram utilizados em substituição de nome(s) de pessoas, instituições ou da denominação do próprio restaurante em análise. 
com a memória local, tão antiga quanto a própria história que é narrada ao leitor/consumidor:

[...] sucede a uma antiga taberna junto à Praça do Geraldo. [A2, p. 26]

[...] herdeira das tradições das antigas tabernas de Évora. [A7, p. 77]

Antiga adega localizada junto à judiaria da cidade [...] convertida em restaurante em 1971. [A6, p. 71]

Quando situado no centro histórico, a história que é contada sobre o restaurante vale-se quase sempre da localização privilegiada, junto de ou a pouca distância de lugares centrais ou monumentos emblemáticos da cidade:

$[\ldots]$ numa das ruas de maior tipicismo urbano [A6]

[...] na antiga zona dos "Chãos Domingueiros", área medieval consolidada no século XVI em torno da cerca monástica de São Francisco e dos Paços Reais de Évora. [A22, p. 194]

Espaço de memória que o liga diretamente à estrutura quinhentista dos Estáus da Coroa [...] [A2, p. 26]

$\mathrm{Na}$ velha Rua dos Mercadores que historicamente ligava a Praça Grande ao bairro judeu da cidade, o restaurante [\#\#\#] tem porta aberta desde 1964. [A8, p. 83]

Num dos casos analisados, a descrição coloca em destaque a localização numa rua cujo topónimo, associado à alimentação, vem do tempo em que “[...] as ruas eram conhecidas pelo nome dos mesteirais que aí viviam e trabalhavam [...]” [A19, p. 164]. Noutros casos enfatizam-se elementos arquitetónicos distintivos do edifício ou espaço mais amplo onde o restaurante está localizado: a sala que mantém a traça de uma antiga casa típica [A6], que inclui e destaca a chaminé alentejana [A22] ou que constitui “[...] um espaço onde se conserva uma tipologia construtiva centenária" [A19, p. 164]. Não raro, o espaço do restaurante é apresentado como indissociável da arquitetura que marca e distingue a cidade, do mesmo modo que o passado é indissociável do presente:

O próprio edifício é uma memória de arquiteturas passadas, dominada pelo branco da cal. [A6, p. 68]

O restaurante [\#\#\#] caracteriza-se pela presença marcante do espaço, de feição rústica, no melhor da tradição histórica do Centro Histórico de Évora. [A22, p. 194]

Nas salas fotografadas abundam elementos decorativos regionais, seja no mobiliário antigo que é preservado, como mesas em pedra "[...] lembrando a das antigas tabernas, as cadeiras de madeira e o balcão de pedra mármore do início do século XX." [A2, p. 29], seja os vários utensílios domésticos que ornamentam o espaço [A6], alguns deles específicos da vida no campo, nomeadamente os relacionados com o manuseamento dos animais ou com as atividades agrícolas tradicionais [A22] (e.g. antigas alfaias agrícolas [A8], chocalhos e cochos [A11]). 
Já quando situados em locais mais afastados do centro histórico, por vezes em freguesias circundantes em que beneficiam de um enquadramento rural [A10], o ambiente da sala é propositadamente decorado tendo em vista uma identificação com a representação social em torno da matriz alentejana. Nesses casos é frequente o recurso a elementos da arquitetura e cultura regional que, embora descontextualizados da sua localização ou função utilitária original, aí servem os propósitos de ornamentação do espaço (e.g. uso de telha típica e outros elementos da arquitetura tradicional relacionada com a pintura das casas, como a cor azul usada tradicionalmente em rodapé, aí colocada em janelas interiores ${ }^{11}$ [A21] e mantas alentejanas que servem a ornamentação das paredes do espaço [A10]). Assim acontece com este restaurante, em cuja descrição se pode ler: "Ainda que situado do lado de fora das muralhas medievais da cidade, junto ao velho Rossio de São Braz, a arquitetura interior do espaço remete para as memórias tipicamente alentejanas." [A11, p. 110).

As fotografias de mesa destes restaurantes traduzem a variada oferta enogastronómica da região. Há uma multiplicidade e diversidade de pratos e uma profusão de cores que acompanha a diversidade dos elementos apresentados: petiscos ou entradas, pratos principais, queijos, doces e vinho. Utilizam-se pratos e panelas típicos em olaria tradicional [A8, A21] e em alguns casos a mesa é ornamentada com recurso à cestaria [A2].

As pessoas fotografadas para dar rosto a estes restaurantes são sobretudo os proprietários, individualmente [A2, A6, A22] ou em casal [A8, A11, A18], por vezes a equipa composta pelo proprietário e a cozinheira [A7] ou o proprietário com o pessoal da cozinha [A21, A10, A19]. Em muitas das descrições, como na que se segue, há uma clara identificação do momento temporal a partir do qual os protagonistas empreenderam este projeto:

No ano de 1999 [\#\#\#] e o seu marido descobriram este lugar maravilhoso carregado de história e com uma arquitetura única. Movidos pela paixão pela gastronomia e pelo desafio de reabilitarem o espaço, construíram ambos estes projeto mantendo-lhe a traça característica e até o nome. [A2, p. 29]

As especialidades identificadas pelos restaurantes decalcam de perto o elenco da gastronomia local, tanto no que respeita às designações de pratos considerados "típicos" da cozinha alentejana: açordas, sopas e ensopados, migas e doçaria conventual, quanto

\footnotetext{
${ }^{11}$ A utilização desta cor na região estará associada à atribuição da referência "Azul Évora" a uma tonalidade específica de azul de acordo com o Color Guide de exteriores das Tintas CIN, uma empresa portuguesa criada em 1917, cuja principal atividade consta no fabrico e comércio de tintas e vernizes. Catálogo disponível online em URL: http://www.cin.pt/portal/ (consulta em 10-11-2017).
} 
no que se refere aos ingredientes base: o pão, as carnes de porco, borrego e caça. Alguns restaurantes destacam o facto de fazerem jus à carta gastronómica ${ }^{12}$, incluindo na sua descrição a referência explícita à oferta de "[...] todos os pratos regionais" [A6] ou dos "pratos típicos da região" [A8].

Do ponto de vista dos valores associados a estes espaços de restauração, enfatizase o respeito pela gastronomia alentejana, exaltado inúmeras vezes nas referências à "identidade", à "matriz tradicional", "regional" ou de "raiz alentejana", em relações comprovadas pelo recurso aos verbos "degustar", "confecionar", "apostar" ou "saborear":

Espaço perfeito para uma degustação "sem pressa", porque é essa a identidade da boa mesa alentejana. [A11, p. 110]

[...] elevada qualidade nos produtos confecionados de matriz tradicional [...] [A10, p. 92]

A sua principal aposta gastronómica é sobretudo a da matriz regional [...] [A18, p. 158]

Nele [restaurante] o cliente pode saborear o melhor da cozinha tradicional alentejana onde não faltam os petiscos de acordo com a sazonalidade dos produtos. [A21, p. 182]

O respeito por esta tradição assenta igualmente na exaltação da qualidade dos produtos, frequentemente associada ao campo e a uma cozinha de inspiração rural, a qual parece ter uma consequência "natural" numa cozinha de "sabor caseiro" que preserva, justamente, "o melhor dos sabores e dos produtos locais":

No seu interior, íntimo e confortável, o cliente é surpreendido por uma cozinha de raiz alentejana, que preserva o melhor dos sabores e dos produtos locais. [A6, p. 68]

A comida, de generoso sabor caseiro nos múltiplos pratos regionais aqui confecionados $[\ldots][$ A 11, p. 110]

[...] o restaurante [\#\#\#] tem apostado na promoção da cozinha regional de inspiração rural e caseira, onde o vinho e o «petisco» são parte integrante da dimensão enogastronómica da mesa alentejana. [A11, p. 113]

As referências ao "tradicional" e "típico" são apresentadas como características não exclusivas dos espaços físicos; extravasam para as pessoas envolvidas na preparação dos alimentos, de que as cozinheiras parecem ser a expressão principal:

[...] a carta aparentemente curta, apesar de constituída por pratos tradicionais muito bem executados, pode revelar surpresas. [...] O tradicionalismo e a típica gastronomia alentejana inundam em abundância a «alma» de cozinheira da D. [\#\#\#]. [A7, p. 74]

De modo explícito, estes restaurantes assumem-se ao serviço da tradição gastronómica regional, que parecem saber "executar" na perfeição, como aliás

${ }^{12}$ A Carta Gastronómica do Alentejo foi compilada pela Confraria Gastronómica do Alentejo em 2013 e publicada pela Entidade Regional de Turismo do Alentejo com o propósito de fazer um "[...] levantamento sistemático do receituário regional, de modo a poder fixar as técnicas, as praticas, os produtos, as épocas e até os nomes das receitas em uso nas cozinhas regionais." (Confraria Gastronómica do Alentejo, 2013, p. $6)$. 
testemunha a participação em iniciativas municipais de promoção gastronómica [A18] ou a distinção com prémios na área [A18].

Nas descrições que apresentam perpassa uma clara orientação e atenção para o cliente, onde este "[...] é tido como a figura principal." [A21, p. 185]. A orientação para o cliente é conseguida, desde logo, através de uma estratégia de aproximação afetiva pela arte "de bem receber", com "amor" e "dedicação". Deste modo, estendem-se ao espaço artificial do restaurante os valores da casa e família, "como se de família se tratasse". Disso mesmo dão conta várias descrições dos espaços analisados:

O ambiente tradicional e acolhedor deste estabelecimento [...] suscita ainda hoje nos que o visitam a sensação de bem-estar, remetendo-os para a sua própria casa e envolvendo-os num ambiente caloroso. [A8, p. 80]

[...] continua hoje fiel ao mesmo princípio, que seja o de bem receber que o visita, como se de família se tratasse, e, desde logo, com amor e dedicação. [A2, p. 29]

[...] adequar a ementa ao gosto do cliente, tornando a degustação num ato familiar e afetivo é o desafio diário [...] [A21, p. 185]

Com um acolhimento familiar, o restaurante aposta na qualidade do serviço, na preservação da boa mesa tradicional e na relação afetiva, tão característica das gentes alentejanas. [A10, p. 95]

[...] o que o cliente encontra é uma sala acolhedora, de ambiente muito agradável e familiar. [A11, p. 110]

Apesar das inúmeras associações, não se trata porém de um restaurante familiar. $\mathrm{Na}$ verdade, a exaltação dos valores familiares funciona como metáfora ao serviço da gestão profissional, de que é estratégia indissociável essa arte de "bem servir" e espelhar a "boa mesa alentejana":

[...] o restaurante [\#\#\#] tem sempre a preocupação de servir bem, fazendo da mesa um momento de conforto, de prazer e de alegria. [A22, p. 194]

A nossa equipa de profissionais, que está sempre em contante formação e aprendizagem, trabalha todos os dias com o objetivo da valorização da gastronomia regional, ajudando à valorização de Évora como importante destino turístico do país. [A18, p. 161]

E ainda que ao longo do tempo o espaço tenha sofrido alterações, nunca perdeu os valores e os princípios de gestão que os seus proprietários lhe imprimiram há meio século atrás: qualidade de atendimento e autenticidade da "boa mesa" alentejana. [A8, p. 83]

Nesta lógica de bem servir, é por via de uma cozinheira oriunda da região e "dotada para as artes da cozinha" que parecem ligar-se as esferas da familiaridade encenada e do profissionalismo assumido. Esta ligação é particularmente notória no caso que se segue, possibilitando no original a leitura do texto em simultâneo com a visualização em tons de preto e branco do retrato da cozinheira na sala do restaurante, com uma chaminé alentejana ao fundo:

[\#\#\#, para além da sua mão dotada para as artes da cozinha, tem a afetividade própria de quem sabe receber bem. Natural da Vidigueira, faz questão de manter vivos os sabores da sua terra, porque, como diz, «há grandes diferenças 
entre o Alto e o Baixo Alentejo». Mas essa diferença, resolvida sobre os mesmos ingredientes e, na essência, sobre o mesmo fundo cultural, é exatamente aquilo que faz o encanto e a autenticidade da gastronomia alentejana. [A22, p. 197]

Em síntese, os espaços de restauração reunidos nesta categoria assumem-se como os guardiães dos sabores típicos e tradicionais da cozinha regional alentejana. Em cenários propícios, seja porque historicamente relacionados com espaços de restauração, seja porque, mais recentes, foram encenados para tal, parecem interpretar sabiamente os guiões da cozinha alentejana. Para isso socorrem-se dos melhores profissionais e nas suas narrativas aderem fortemente à missão de respeitar e preservar "a boa mesa alentejana", numa simbiose inextricável que agrega história e gastronomia ao serviço do cliente. A descrição que se segue é especialmente elucidativa desta missão:

Nele [restaurante] se tem preservado, não só a integridade do espaço histórico, como a tradição da cozinha regional. A esta associação entre o edificado histórico e o respeito pela cozinha de tradição, acresce a eficiência e qualidade do serviço, fatores que têm determinado o sucesso deste restaurante, um dos mais antigos e respeitáveis que mais tem contribuído para a excelência da oferta gastronómica de Évora. [A6, p. 71]

\subsection{De geração em geração, o segredo da cozinha alentejana}

O cenário parece ser menos importante que a história dos próprios restaurantes nos casos em que se afirma uma gestão eminentemente familiar. Surgem principalmente localizados "em pleno centro histórico" [B3], mas também em espaços menos centrais. Agrega-os uma autenticidade que advém do facto de terem sido fundados pela família para os fins da restauração, propósito sempre referido nas descrições apresentadas em que não falta a datação a comprovar a inscrição no ramo:

O restaurante [\#\#\#], fundado em 1945 sob traços tradicionais e gestão familiar [...] [B3, p. 38]

Fundado em 1945 por [\#\#\#] e continuado pelos filhos [\#\#\#, este emblemático restaurante eborense começou por ser uma simples taberna como era comum na época. [A8, p. 41]

Com origem numa taberna típica alentejana, o restaurante [\#\#\#] é, há mais de 42 anos, gerido pela família [\#\#\#] [B12, p. 119]

O Restaurante [\#\#\#] começou a funcionar no dia 11 de Setembro de 1977, no antigo espaço da taberna do [\#\#\#]. [B17, p. 155]

Nesta categoria, a história do espaço impõe-se como estruturante da apresentação que é feita do restaurante: o restaurante é aquele espaço em concreto e aquele espaço é e faz o restaurante. As duas histórias entrelaçam-se, assim como as vidas que compõem gerações distintas dentro de uma mesma família:

Imagem de marca desta antiguidade é a entrada do restaurante que coincide com um dos arcos do velho Aqueduto da Água da Prata (1533-1537), junto da 
qual dispõe de uma esplanada onde o cliente pode usufruir da beleza histórica da cidade. [B17, p. 152]

Quando localizado fora do centro histórico, destaca-se uma vez mais a história do espaço, inscrito na biografia do(s) proprietários(s) e, por isso, única e distintiva:

[...] o restaurante está inserido em ambiente campestre e bastante pitoresco, com os seus jardins cuidados pelo proprietário, [\#\#\#]. A quinta oferece também muitos dos vegetais e frutas que se consomem no restaurante o que reforça a qualidade e a sazonalidade da cozinha tradicional praticada no restaurante. [B5, p. 62]

Nas descrições apresentadas, a sala de refeições parece não ser tão valorizada do ponto de vista da sua ornamentação, privilegiando-se outrossim o espaço que a acolhe, a história e o ambiente aí proporcionado:

Decoração clássica, inspirada em artigos de caça e faianças. [B3] [...] ambiente elegante e acolhedor [B12]

[...] [decoração] simples mas elegante que se enquadra perfeitamente no edifício centenário onde está instalado, é um espaço muito agradável com abóbodas apoiada em arcaria. [B17, p. 152]

A mesa é farta e colorida e as especialidades contemplam, globalmente, "todos os pratos típicos da região" [B5].

Nos rostos escolhidos para retratar estes restaurantes é a família que sobressai, sempre marcada por duas ou mais gerações: o pai ao centro, de pé e os dois filhos, sentados, um de cada lado [B3]; a filha ao centro, em pé, e os pais sentados, um de cada lado [B5]; mãe e filho [B12]; ou pai e filha [B17]. A gestão familiar contribui para sublinhar os valores de qualidade associados à antiguidade do espaço transmitido de geração em geração (destacaram-se já as diversas referências à datação e fundação dos espaços). A longevidade é apresentada como sinónimo de "empenho" e "dedicação" da parte da família, mas também de "qualidade" e "respeito pelo receituário tradicional":

Na liderança do restaurante permanece o primogénito [\#\#\#, contando hoje com o empenho da terceira geração [...]. [B3, p. 41]

A sua longevidade está alicerçada na qualidade dos produtos, na dedicação e na hospitalidade, a par do integral respeito pelo receituário tradicional, partilhado por uma excelente e fiel equipa de profissionais. [B3, p. 38]

Agora, já com o apoio dos filhos, ambos sentem o orgulho na sua «casa» que se transformou com o tempo num restaurante de referência em Évora. E têm razão em estarem orgulhosos da obra feita, pois que, além de manter a tradição gastronómica regional, também sabem honrar a melhor tradição alentejana de bem receber. [B5, p. 65]

Depois de 36 anos de atividade e com duas gerações da família [\#\#\#] na sua cozinha, a sua cozinha mantem-se fiel à gastronomia tradicional alentejana [...]. [B17, p. 155]

A antiguidade traz também o reconhecimento pela "[q]ualidade do serviço e arte de bem confecionar" [B17], tanto por parte de eborenses quanto de turistas. Estes méritos 
parecem justificar os prémios recebidos, assim como a inclusão do restaurante em vários roteiros turísticos europeus [B17], a representação de Portugal em eventos e iniciativas de promoção da gastronomia, as referências nos guias, o reconhecimento nos prémios acumulados [B3] e nos destaques pela imprensa da especialidade [B17].

Em suma, de modo diferente dos restaurantes incluídos na categoria anterior, guardiães dos sabores típicos e tradicionais da cozinha regional alentejana, que executam na perfeição, os restaurantes aqui tratados parecem ser os guardiães de saberes que transmitem na gastronomia tradicional alentejana. De modo muito vincado, a família é apresentada como o fiel depositário do saber que envolve a confeção dos pratos tradicionais. Um saber que se transmite de geração em geração, entre avós e netos e de mão em mão, sem "artifícios" e onde os segredos preservados são garante de "respeito", "tradição", "qualidade" e "autenticidade":

Este restaurante que respeita integralmente a tradição rural da boa cozinha alentejana pelas mãos experientes da Dona [\#\#\#] [...] dá o seu talento à cozinha tradicional alentejana, cujos segredos aprendeu com a sua avó [...]. [B5, p. 62-65]

Os melhores pratos, confecionados com produtos da mais alta qualidade [...] proporcionando o melhor da cozinha Alentejana, sem artifícios, mas com uma riqueza de aromas e sabores que a tornam absolutamente irresistível. [B12, p. 116]

\subsection{A reinvenção da cozinha alentejana, e os sentidos (sempre) aqui tão perto}

Um conjunto de outros restaurantes parece instalar-se espacialmente em locais de grande impacto, seja pela associação a lugares emblemáticos do ponto de vista histórico, seja pelas características distintivas da arquitetura ou paisagem envolvente. Em alguns casos, adiantam-se as coordenadas históricas que (de)marcam o espaço e contexto:

\footnotetext{
Edifício do século XVI [C23]

antiga adega quinhentista [C1]

localizado junto à muralha medieval e quase debaixo do passadiço quinhentista de D. Jorge Henriques, falcoeiro-mor de D. João III [C9, p. 86]

Restaurante moderno e sofisticado, localizado na antiga zona da mouraria de Évora, perto do templo romano [...] [C13, p. 128)

[...] situado junto ao antigo mosteiro de São Domingos. [C14]
}

Noutros casos, sobretudo quando as fotografias não são explícitas sobre a qualidade ou excecionalidade do espaço, é necessário contar e pormenorizar a história desse lugar:

[\#\#\#] está localizado na principal praça de Évora, no espaço dos antigos Estaus da Coroa, primitiva estalagem régia portuguesa do século XV que antecedeu os paços reais de S. Francisco. Aqui pernoitavam embaixadores e outros dignitários aquando da permanência da corte em Évora. Diz a tradição que foi também nas caves deste local que se arquitetaram as Alterações de 1637, 
movimento contestatário ao governo filipino que prenunciou a Restauração de 1640. [C20, p. 176]

Os espaços são valorizados não apenas por aquilo que encerram mas também pelo que deixam ver, através ou para além deles: o ambiente no exterior, numa agradável noite de verão [C14], ou uma "vista exclusiva sobre a cidade." [C20, p. 176]. Sobretudo quando afastados do centro histórico ou da história dos grandes rostos e eventos, sublinha-se a envolvente com a paisagem alentejana:

Com vista sobre o montado alentejano e para a horta biológica e de ervas aromáticas do hotel, promove a gastronomia regional com um toque de modernidade, utilizando produtos locais e de época, acompanhados por uma garrafeira de vinhos alentejanos de excelente qualidade. [C15, p. 140]

[...] a cinco minutos do Centro Histórico, e tem uma sala confortável com decoração em tons terra e amplas janelas para o espaço verde circundante [...] Pela sua localização é um ótimo local para tomar um cocktail ou um vinho alentejano, enquanto se disfruta do pôr-do-sol sobre a serra de Montemuro. [C4, p. 44]

Associados a unidades hoteleiras de importância considerável na cidade $[\mathrm{C} 1, \mathrm{C} 4$, C15], embora não exclusivamente, as salas destes restaurantes oscilam entre a disposição mais habitual de uma sala de refeições de "decoração elegante e sóbria" [C23], "um espaço agradável e requintado" [C14], aberto, tipo lounge [C13 e C14], boutique bar [C16] ou restaurante bar [C20]. Nestes últimos, as descrições enfatizam um local de ambiente "simpático", “jovem", "acolhedor" e "sossegado":

Em pleno coração da cidade, o [\#\#\#] é muito mais do que um simples restaurante: é um lounge com um ambiente simpático, jovem, acolhedor e sossegado. [...] o restaurante diferencia-se pelo seu espírito jovem e original. [C14, p. 134-137]

As fotografias acentuam os traços gerais da arquitetura peculiar que serve de enquadramento ao restaurante ou pequenos detalhes que assinalam um ambiente distinto: ogivas quinhentistas [C1], ambiente à média luz [C1], cores sóbrias como os vermelhos [C1] ou lilás [C13] para um ambiente "moderno e sofisticado" [C13, p. 128] num espaço "moderno e contemporâneo" [C13, p. 131]. Grosso modo, há uma harmonia das cores e texturas que, reconhecidamente, não é fruto do acaso: "Todo o restaurante [\#\#\#] foi pensado, quer o seu espaço interior quer o exterior, de forma harmoniosa." [C15, p. 140]. Em alguns casos, as fotografias revelam uma sala de decoração extravagante, moderna e cosmopolita que caracteriza a personalidade do espaço ou dos proprietários:

O projeto, concebido de raiz à imagem dos proprietários [\#\#\#, foi desenvolvido e decorado de acordo com o potencial do próprio espaço e gosto dos proprietários. Por isso a aposta foi a de um ambiente romântico e requintado, acompanhado de música ambiente e iluminação das mesas à luz das velas. [C9, p. 89] 
A apresentação da mesa prima pela contenção. É menos abundante em quantidade, diversidade e cor e uma certa estética gastronómica (MIELE; MURDOCK, 2002) parece impor-se de modo particularmente pronunciado. Os pratos podem ser ornamentados com flores [C1] e castiçais de cristal iluminam a mesa [C1].

O protagonista que dá rosto ao restaurante é o proprietário [C13, C16, C4] mas sobretudo o chef [C1, C9, C14, C15, C23, C20]. Profissional de excelência, apresenta-se sempre de jaqueta [C1], às vezes inclusivamente de toque blanche [C9]. A mensagem personalizada que acompanha a descrição da fotografia acentua precisamente o papel do chef, que através das suas "mãos" recria os sabores da gastronomia local e recoloca-os num contexto marcado pelos "mais elevados padrões de qualidade":

Neste espaço o cliente tem o raro privilégio de provar os requintados sabores
da gastronomia local, de forte inspiração mediterrânica, recriados pelas
experientes mãos de um reputado chefe de cozinha e servidos pelos mais
elevados padrões de qualidade, num ambiente dominado pela extraordinária
dimensão histórica e patrimonial do edifício, datado de 1552. [C1, p. 23]

Não raro, aliás, cita-se a formação do chef: os locais onde fez formação, por onde passou e as distinções obtidas são utilizadas como argumento para a reivindicada qualidade do restaurante:

Formado na Escola [\#\#\#], conseguiu introduzir inovação e criatividade na sua ementa, mantendo, no entanto, os sabores alentejanos no seu todo. [...] Procurando criar algo que se demarcasse da restauração existente em Évora, [\#\#\#] combinou a cozinha tradicional alentejana com a sua experiência nos melhores restaurantes gourmet do país. [C14, p. 137]

[...] distinguido como Bib Gourmand no Guia Michelin, desde 2011. [C9, p. 86]

As especialidades utilizam os produtos regionais base, como seja a carne (borrego ou porco), a caça (lebre) e o peixe (cação), a par de outros produtos regionais, como o vinho, ainda que a confeção resulte numa cozinha "diferente" [C13]. São vários os fatores que parecem concorrer para esta diferença. Por um lado, uma apresentação distinta, quase enigmática, que resulta dos substantivos utilizados para dar corpo aos pratos, como sejam a "almofada", o "estaladiço", a "crosta" ou a "textura":

Almofada de porco preto [C9]

Salada de ovinhos com estaladiço de paio [C23]

Cogumelo assado em crosta de farinheira [C23]

Lombinho de porco recheado com farinheira e textura de batata [C23]

Por outro lado, a experiência internacional e influência cosmopolita que os chefs imprimem nos pratos, de que é exemplo o Risotto de vieira [C13] ou Risotto de lavagante [C1], a Costeleta de vitela em papillote [C13] ou o Carré de Borrego [C15]. 
Por fim, o apelo multissensorial, visível na combinação através de "perfumes", "movimentos" ou "texturas" de ingredientes ou produtos de junção invulgar:

Robalo perfumado com poejo e funcho [C1]

Dueto de porco do montado alentejano com miga de espargos [C1]

Subtilezas conventuais em três texturas [C1]

Em resultado, a especificidade destes restaurantes passa também pela capacidade de surpreender o cliente:

O Chef [\#\#\#] não confeciona nenhuma especialidade específica, todos os pratos que se encontrem no menu são elaborados de maneira a que os clientes tenham uma agradável surpresa com os sabores, as técnicas e as apresentações dos pratos que escolherem. Por isso, poder-se-á dizer que a especialidade do chef é surpreender os clientes com os pratos que lhe apresenta $[\ldots][\mathrm{C} 15, \mathrm{p}$. 143]

Como valores que atravessam estes espaços destaca-se a qualidade, diferenciação, criatividade, originalidade e contemporaneidade. De modo mais explícito que em qualquer das categorias antecedentes, e com exceção para os espaços integrados em unidades hoteleiras, estes restaurantes assumem-se como "projetos" e "sonhos concretizados", desejados e pensados pelos seus empreendedores como espaços "únicos" e "diferentes" dos demais, onde muitas vezes o proprietário coincide com o chef:

O projeto nasceu em 1986 com o restaurante [\#\#\#], onde se verificou a necessidade de apresentar novas especialidades gastronómicas de acordo com as necessidades e o gosto dos clientes, mas mantendo a tradição da cozinha regional. [C13, p. 131]

[\#\#\#, com apenas 25 anos, aventurou-se naquele que foi um ato de puro empreendedorismo: fundou o seu próprio restaurante a partir do zero. [C14, $\mathrm{p}$. 137]

No ano de 2007, [\#\#\#] concretizou o sonho de abrir no Centro Histórico de Évora o seu próprio restaurante, a que lhe deu o seu primeiro nome. [C9, p. 89] [...] resultou da paixão do proprietário pelo vinho, pelo prazer da boa mesa e pelo convício gastronómico que ela suscita. [...] Sem nunca descurar a sua paixão enogastronómica, aos 40 anos, por circunstâncias da vida, acaba por ter a oportunidade de concretizar um sonho adiado, que apesar de ser só seu, também o comunga com os avós, pai e irmão. [C16, p. 146-149]

Estes projetos passam ainda pela inovação e reinvenção da cozinha tradicional, o que surge associado a uma cozinha de autor, característica que vem acentuar o carácter simultaneamente excecional, raro ou elaborado dos pratos:

Para além dos melhores pratos de cozinha tradicional alentejana, o restaurante aposta numa cozinha de autor, inovando e recriando receitas diferentes. [C9, p. 86]

Consequentemente, estes espaços apostam na personalização do serviço, orientado não para $o$ cliente mas para um cliente em particular, a quem se procura proporcionar uma experiência única e diferente:

O [\#\#\#] serve comida portuguesa confecionada como se fosse para um único cliente, em que pratos como [...] são elaborados e servidos num verdadeiro 
«slow food concept». Este conceito estende-se também à nossa filosofia da degustação de uma refeição, onde um almoço tem a duração de uma tarde e um jantar de uma noite inteira, e onde se preza o convívio e a partilha de experiências. [C20, p. 179]

No conjunto, os espaços agrupados nesta categoria dão conta de um convite permanente a uma experiência única, diversificada e multissensorial:

[...] é um restaurante de cozinha gourmet onde o passado e o presente se fundem numa experiência única, simultaneamente sensorial e afetiva. [C1, p. 20]

[o restaurante] tem apostado numa carta gastronómica que alia a criatividade da cozinha à excelência dos produtos regionais. A variedade e a qualidade da cozinha mantêm-se fiéis à tradição da boa mesa alentejana, com pratos diários, e às sugestões do chef, que todos os dias diferem. [C9, p. 86]

O restaurante liberta-se de um conceito previsível, rígido e imóvel e reinventa-se na surpresa, plasticidade e volatilidade das experiências que proporciona ao cliente, em ambientes e contextos que variam entre o passado e o presente, do espaço exterior da esplanada para o espaço interior, do dia para a noite, ao longo da semana ou até mesmo do ano:

Desfrute de umas tapas ao ar livre no terraço nas noites de verão, ou de uma refeição no seu interior, decorado com traços modernos e tradicionais [C14, p. 134]

[...] restaurantes que marquem pela diferença, delineando um conceito novo: atrair os locais e os turistas, com uma carta que muda consoante a estação do ano, mas onde a identidade se mantém intacta. [C14, p. 137]

[...] ao almoço oferece um ambiente mais descontraído em que o cliente procura uma refeição informal. Durante o jantar sobressairá todo o requinte do espaço que impressiona pela recuperação do edificado arquitetónico e por um ambiente 'cozy' que convida o visitante a refeições mais alargadas mas sem formalidades excessivas. [C23, p. 200]

Afirma-se, por fim, a experiência gastronómica como um happening, uma "festa" que é também a celebração da individualidade, criatividade, refinamento e experiência profissional que urge "descobrir", "degustar" e "celebrar":

O espaço é uma fusão entre restaurante convencional e a wine house, simbolicamente representado pela pipa de vinho revitalizada num novo conceito e, como tal, surge em Évora como um projeto empreendedor de cozinha e de vinhos centrado na satisfação do cliente. Nas palavras do seu mentor a [\#\#\#], é uma festa. [C16, p. 146]

\section{Conclusão}

Este texto procurou identificar e contextualizar as estratégias discursivas utilizadas para apresentar os restaurantes de Évora. Com base no livro Comer em Évora: os restaurantes e as suas receitas, do fotógrafo português Jerónimo Heitor Coelho, foram analisadas fotografias e pequenos textos utilizados para apresentar, descrever e promover um conjunto de 23 restaurantes da cidade. Através de uma análise qualitativa de conteúdo 
que olhou principalmente a cenários, protagonistas e guiões, distinguiram-se três categorias diferentes de restaurantes, os quais estabelecem relações diferenciadas com a cozinha alentejana.

Embora circunscrito a uma obra em particular, este estudo permite extrair conclusões interessantes, tanto do ponto de vista da investigação, quanto da ação. Desde logo, vem (re)afirmar a importância e urgência de desenvolver mais investigação em torno da literatura enogastronómica. Como ficou demonstrado, esta literatura é particularmente rica porque permite compreender nos interstícios da apresentação, promoção e marketing todo o processo de construção social de lugares e representação de destinos através de determinadas formas de escrita e apresentação visual, cujas estratégias estão ainda por desvendar na totalidade.

A análise das narrativas textuais e visuais com base nos princípios de storytelling sustenta a conclusão de que a construção social de lugares e a representação de destinos é alimentada por histórias que se (re)contam tendo por base determinados espaços, nos quais habitam protagonistas específicos que se regem por guiões definidos. Uma primeira categoria agrega os espaços de restauração que se assumem como os guardiães dos sabores típicos e tradicionais da cozinha regional alentejana. Em cenários historicamente relacionados com espaços de restauração ou noutros mais recentes mas propositadamente encenados para tal, parecem interpretar sabiamente os guiões da cozinha alentejana. Para isso socorrem-se dos melhores profissionais e nas suas narrativas aderem fortemente à missão de respeitar e preservar "a boa mesa alentejana", numa simbiose inextricável que agrega história e gastronomia ao serviço do cliente.

De modo diferente, outros restaurantes parecem ser os guardiães de saberes que transmitem na gastronomia tradicional alentejana. Nesses casos, a família é apresentada como o fiel depositário do saber que envolve a confeção dos pratos tradicionais. Um saber que se transmite de geração em geração, às vezes entre avós e netos, outras de pais para filhos, mas sempre de mão em mão, sem "artifícios" e onde os segredos preservados são garante de "respeito", "tradição", "qualidade" e "autenticidade".

Os espaços agrupados na última categoria dão conta de um convite permanente a uma experiência única, diversificada e multissensorial. O restaurante liberta-se de um conceito previsível, rígido e imóvel e reinventa-se na surpresa, plasticidade e volatilidade das experiências que proporciona ao cliente, em ambientes e contextos que variam entre o passado e o presente, do espaço exterior da esplanada para o espaço interior, do dia para a noite, ao longo da semana ou até mesmo do ano. Afirma-se, por fim, a experiência gastronómica como um happening, uma "festa" que há que "degustar" e "celebrar". 
Em suma, ao mesmo tempo que se afirma como lugar único, o destino turístico é socialmente construído como um espaço diversificado de consumo. (Re)inventando-se a tradição (Hobsbawn, 1983), de um lado reforça-se o estereótipo cultural em torno da tradicional cozinha alentejana; de outro, afirma-se uma cozinha diferente, criativa, inovadora e exótica, no sentido em que ultrapassa as regras do que é aceitável e esperado, aproximando-se inclusivamente, em alguns casos, de uma gastronomia "de última geração", com recurso a técnicas de esferificação, emulsão, gelificação ou espumas. Transversalmente, as estratégias discursivas utilizadas passam pela ênfase na história, tradição, autenticidade e personalização, seja pela via familiar, seja pela figura do chef e cozinha de autor.

A par das redes sociais, livros como este podem sem dúvida desempenhar um papel decisivo no aumento da literacia do turista em torno dos locais que visita, assim como na avaliação que deles faz. No caso particular dos espaços de restauração, a esta literacia por parte dos visitantes deverá corresponder igual literacia por parte da comunidade anfitriã, nomeadamente no que respeita ao conhecimento e valorização da gastronomia local. Assim, torna-se necessário assegurar formação diversificada, nomeadamente em tópicos de história, cultura local e regional, incluindo food menu, e que permita abordar questões que vão desde a gastronomia tradicional aos alimentos de quinta gama, inovação e tendências atuais em gastronomia, mas também wine list, ou seja, formação específica na área da enologia e vinhos, que englobe o conhecimento das características físico-químicas e sensoriais dos vinhos elaborados a partir de castas nacionais e internacionais, os diferentes tipos de vinhos, harmonizações de vinhos e alimentos, bem como outras interações e sinergias entre vinhos e alimentos.

A concluir, comprovado o enorme potencial dos métodos visuais na criação de (novos) conhecimentos e contributos para os estudos em turismo, espera-se que este texto possa encorajar e inspirar investigadores e estudantes a serem inovadores e criativos na utilização dessas metodologias. Deste modo será possível pensar e estudar o turismo, e as suas múltiplas dimensões e implicações, de uma forma simultaneamente teórica e empírica. Obrigatoriamente, também ética e interdisciplinar.

\section{Agradecimentos}

Uma versão preliminar deste artigo foi inicialmente pensada para apresentação de uma comunicação oral ao painel temático "Gastronomia, Turismo e Desenvolvimento" no âmbito do IV Curso Internacional de Verão da Escola de Ciências Sociais da Universidade de Évora, agendado para Setembro de 2014 sob o título "Agricultura Familiar, Alimentação e Desperdício Alimentar". Vicissitudes várias fizeram com que 
este Curso não viesse a ser realizado; tão-pouco surgiu - até esta data - outra oportunidade de aprofundar o trabalho antes iniciado. Este texto não seria possível sem a influência indelével de Francisco Martins Ramos (1943-2017), antropólogo português e meu antigo Professor, a quem devo as primeiras incursões nas áreas da Sociologia e Antropologia da Alimentação e do Turismo, ainda durante a licenciatura em Sociologia na Universidade de Évora, Portugal (1994/98). Agradeço também a Denise Lawrence-Zúñiga, cujas aulas no Mestrado em Sociologia na Universidade de Évora (2000/2001) foram decisivas para pensar cientificamente objetos da cultura (i)material alentejana à escala global. Seriam precisos muitos mais anos para voltar a este tema; regresso ironicamente possibilitado pelos (im)previstos da distribuição anual de serviço docente e pela organização e dinamização de atividades extracurriculares que me têm mantido relativamente próxima de estudantes e investigadores na área dos estudos de turismo.

\section{Referências}

AMARAL, R.; et al. Gastronomy and Wines in the alentejo Portuguese Region: Motivation and satisfaction of tourists from Évora. In: PERIS-ORTIZ, M.; et al. (Eds.). Wine and Tourism: A strategic segment for sustainable economic development. 1. ed. Cham: Springer, 2016. p. 179192.

BANKS, M. Using Visual Data in Qualitative Research. 1. ed. Sage: London, 2007.

BARDIN, L. L’Analyse de Contenu. 1. ed. Paris: Presses Universitaires de France, 1977.

BAUMAN, Z. Consuming Life. 1. ed. Cambridge: Polity Press, 2007.

BEARDSWORTH, A.; KEIL, T. Sociology on the Menu: An Invitation to the Study of Food and Society. 1. ed. Oxon: Routledge, 1997.

BILOU, F. Comer em Évora com um pouco de história. In: COELHO, J. H. Comer em Évora: os restaurantes e as suas receitas. 1. ed. Mem Martins: Visual Factory, 2014. p. 13-14.

BORGES, M. R.; SERRA, J.; MARUJO, N. Visitor profiles at world cultural heritage sites: an empirical study of Évora, Portugal. In: JIMÉNEZ, J.M.; et al. (Eds.). Methods and Analysis on Tourism and Environment. 1. ed. New York: Nova Science Publishers, 2013. p. 93-108. BOURDIEU, P. La Distinction. 1. ed. Paris: Seuil, 1979.

BRIEN, D. L.; WESSELL, A. Cookbook: A New Scholarly View. M/C Journal, Queensland, v. 16, n. 3, s.p., june. 2013. Disponível em: <http://journal.media-

culture.org.au/index.php/mcjournal/article/view/688>. Acesso em: 12 nov. 2017.

CHANEY, D. Lifestyles. 1. ed. London: Routledge, 1996.

COELHO, J. H. Comer em Évora: os restaurantes e as suas receitas. Mem Martins: Visual Factory, 2014. 
CONFRARIA GASTRONÓMICA DO ALENTEJO. Carta Gastronómica do Alentejo.

Monumenta Transtaganae Gastronomica. S.1.: Entidade Regional de Turismo do Alentejo. 2013.

COSTA, R. On the Timelessness and Timeliness of Categorical Analysis: the Past, Present, and Yet to Come of searching for Latent Meanings. Communication Studies, Covilhã , v. 19, p. 79-106, may. 2015.

COSTELLO, M. Reading the Senses: Writing about Food and Wine. M/C Journal, Queensland, v. 16, n. 3, s.p., june. 2013. Disponível em: <http://journal.mediaculture.org.au/index.php/mcjournal/article/view/651>. Acesso em: 06 out. 2017.

FEATHERStOnE, M. Consumer Culture and Postmodernism. 1. ed. London: Sage, 1991.

FERGUSON, P. P. A Cultural Field in the Making: Gastronomy in 19th Century France.

American Journal of Sociology, Chicago, v. 104, n. 3, p. 597-641, nov. 1998.

FERGUSON, P.; ZUKIN, S. What's Cooking? Theory and Society, Dordrecht, v. 24, n. 2, p. 193-99, apr. 1995.

FLICK, U. Métodos Qualitativos na Investigação Científica. 1. ed. Lisboa: Monitor, 2005.

GABRIEL, Y.; LANG, T. The Unmanageable Consumer - Contemporary Consumption and its Fragmentation. 1. ed. London: Sage, 1995.

GALOPIM DE CARVALHO, A. M. Prefácio. In: COELHO, J. H. Comer em Évora: os restaurantes e as suas receitas. 1. ed. Mem Martins: Visual Factory, 2014. p. 7-8.

GLASER, B.; STRAUSS, A. The Discovery of Grounded Theory: Strategies for Qualitative Research. 1. ed. Chicago: Aldine Publishing Company, 1967.

GRONOW, J. The Sociology of Taste. 1. ed. London: Routledge, 1997.

HALL, C. M. et al. (Eds.). Food Tourism around the World: Development, Management and Markets. 1. ed. Oxford, UK: Butterworth-Heinemann, 2003.

HOBSBAWN, E.; RANGER, T. The Invention of Tradition. 1. ed. Cambridge: University Press, 1983.

JOHNSTON, J.; BAUMANN, S. Democracy versus Distinction: A Study of Omnivorousness in Gourmet Food Writing. American Journal of Sociology, Chicago, v. 113, n. 1, p. 65-204, jul. 2007.

JOKELA, S.; RAENTO, P. Collecting visual materials from secondary sources. In: RAKIĆ, T.; CHAMBERS, D. (Ed.). An Introduction to Visual Research Methods in Tourism. 1. ed. London: Routledge, 2012. p. 53-69.

KIM, Y. G.; EVES, A.; SCARLES, C. Building a model of local food consumption on trips and holidays: A grounded theory approach. International Journal of Hospitality Management, Amsterdam, v. 28, p. 423-431, sept. 2009.

KIVELA, J.; CROTTS, J. C. Gastronomy tourism: A meaningful travel market segment. Journal of Culinary Science and Technology, Philadelphia, v. 4, n. 2-3, p.39-55, sep. 2005.

KLANTEN, R.; EHMANN, S.; SCHULZE, F. Visual Storytelling: Inspiring a New Visual Language. 1. ed. Berlin: Gestalten Verlag, 2011. 
KORSMEYER, C. (Ed.). The Taste Culture Reader: Experiencing Food and Drink. 1. ed. Oxford: Berg Publishers, 2005.

KRIPPENDORFF, K. Content Analysis: An Introduction to Its Methodology. 2. ed. Beverly Hill, CA: Sage Publications, 2003.

LÉVI-STRAUSS, C. Le Triangle Culinaire. L’Arc, Aix-en-Provence, n. 26, p. 19-29. 1965.

MARUJO, N.; SERRA, J.; BORGES, M. R. Visitors to the city of Évora: Who are they? European Journal of Tourism, Hospitality and Recreation, Leiria, v. 3, n. 2, p. 91-108. 2012.

MIELE, M.; MURDOCK, J. The Practical Aesthetics of Traditional Cuisines: Slow Food in Tuscany. Sociologia Ruralis, Assen, v. 42, n. 4, p. 312-328, oct. 2002.

MILLER, D. (Ed.). Acknowledging Consumption. 1. ed. London: Sage, 1996.

PALMER, C. Moving with the Times: Visual representations of the tourism phenomenon. Journal of Tourism Consumption and Practice, v. 1, n. 1, p. 74-85. 2009.

PINK, S. Doing Visual Ethnography. 1. ed. London: Sage, 2001.

POULAIN, J.-P. Sociologies de l'Alimentation. 1. ed. Paris: Presses Universitaires de France, 2002.

PROSSER, J. (Ed.). Image-based Research: A Sourcebook for Qualitative Researchers. 1. ed. London: Falmer Press, 1998.

QUITÉRIO, J. Gastronomia e a Identidade Cultural. Santarém: Ed. Festival Nacional de Gastronomia, 1994.

RAKIĆ, T.; CHAMBERS, D. (Ed.). An Introduction to Visual Research Methods in Tourism. 1. ed. London: Routledge, 2012.

RAMOS, F. M. A Cozinha Alentejana. In RAMOS, F. M. Breviário Alentejano. Casal de Cambra: Caleidoscópio, 2006. p. 94-98.

RAMOS, F. M. Vinho do Alentejo. Temas Culturais. 1. ed. Lisboa: Edições Colibri, 2010.

ROSE, G. Visual Methodologies: An Introduction to the Interpretation of Visual

Materials. 1. ed. London: Sage, 2001.

SARAMAgO, A. Gastronomia Património Cultural: Com os Olhos Postos no Futuro, Reflexões sobre o Turismo em Portugal. 1. ed. Lisboa: Ed. Ministério da Economia, 2002.

SCARLES, C. Where words fail, visual ignite: Opportunities for visual autoethnography in tourism research. Annals of Tourism Research, New York, v. 37, n. 4, p. 905-926, oct. 2010.

SHIRATO, T.; WEBB, J. Reading the Visual. 1. ed. Crows Nest: Allen \& Unwin, 2004.

SILKES, C.; CAI, L.; LETHO, X. Marketing to the Culinary Tourist. Journal of Travel \& Tourism Marketing, v. 30, n. 4, p. 335-349, may. 2013.

SIMPLÍ́CIO, M. D.; CAMELO, N. S. O reforço do turismo como setor estruturante em Évora. Cadernos de Geografia, Coimbra, v. 34, s.n., p. 43-52, 2015. 
SIMS, R. Food, place and authenticity: local food and the sustainable tourism experience. Journal of Sustainable Tourism, Clevedon, v. 17, n. 3, p. 321-336, may. 2009.

SMITH, V. L. (Ed.). Hosts and Guests. The Anthropology of Tourism. 1. ed. Philadelphia. University of Pennsylvania Press, 1977.

SOUTHERTON, D. Analysing the Temporal Organization of Daily Life: Social Constraints, Practices and their Allocation. Sociology, Manchester, v. 40, n. 3, p. 435-454, june. 2006.

TURISMO DE PORTUGAL. Gastronomia e Vinhos. Lisboa: Turismo de Portugal, 2006.

TURISMO DE PORTUGAL. Plano Estratégico Nacional do Turismo. Revisão e Objetivos 2013-2015. Lisboa: Turismo de Portugal, 2013.

UNWTO. UNWTO Tourism Highlights: 2017 Edition. Madrid: United Nations World Tourism Organisation, 2017.

URRY, J. The Tourist Gaze. 1. ed. London: Sage, 1990.

URRY, J. Consuming Places. 1. ed. London: Sage, 1995.

WARDE, A. Consumption, Food and Taste - Culinary Antinomies and Commodity

Culture. 1. ed. London: Sage, 1997.

WARDE, A. Consumption and Theories of Practice. Journal of Consumer Culture, v. 5, n. 2, p. 131-153, july. 2005.

Recebido em: 02 de janeiro de 2018.

Aceito em: 24 de outubro de 2018. 